\title{
技術論文
}

\section{紫外線照射処理および熱処理した 磁気ディスク潤滑膜の機械特性の評価}

\author{
黒 坂 渡 ${ }^{\mathrm{a},{ }^{*}}$, 三 宅 正二郎 ${ }^{\mathrm{a}}$ \\ ${ }^{a}$ 日本工業大学 工学部 $($ T 345-8501 埼玉県南埼玉郡宮代町学園台 4-1)
}

\section{Evaluation of Mechanical Properties of Lubricant-Coated Magnetic Disk Subjected to Ultra-Violet Irradiation and Heat Treatment}

\author{
Wataru KUROSAKA ${ }^{\text {a,* }}$ and Shojiro MIYAKE ${ }^{\text {a }}$
}

\begin{abstract}
${ }^{a}$ Faculty of Engineering, Nippon Institute of Technology (4-1, Gakuendai, Miyashiro-machi, Minamisaitama-gun, Saitama 345-8501)
Using atomic force microscopy (AFM), nanoindentation, nanowear, and viscoelastic testing were performed to elucidate nanomechanical properties of lubricant-coated magnetic disks. The surface deformation resistance of an ultraviolet (UV)-irradiated disk is superior to those of heat-treated or untreated disks. Evaluation of viscoelastic change using nanowear tests revealed that, for the UV-irradiated and untreated magnetic disks, $\tan \delta$ does not decrease with friction. However, for the heat-treated disk, $\tan \delta$ decreases with sliding. This result demonstrates the resupply capability of the UV-irradiated and untreated lubricant-coated disks during sliding. The lubricant-coated magnetic disks' friction properties are evaluated using the ball-on disk friction test. The UV-irradiated magnetic disk exhibits stable friction coefficients, and less friction damage than the other. These superior properties of the UV-irradiated magnetic disk can be understood in terms of nanomechanical properties evaluated using AFM. The UV-irradiated disk has suitable bonding strength between the lubricant and DLC, in addition to the resupply capability of the free lubricant.
\end{abstract}

Keywords : PFPE Lubricant, Force Modulation, AFM

\section{1.はじめに}

情報産業の発展には目覚ましいものがあり，その中でヘッ ドと記録媒体との相対運動を基本原理とする磁気ディスクや 光ディスクなどのファイル記憶装置が大きな役割を果たして いる。磁気記録は光記録とともに記録密度を大幅に向上させ, 高密度記録化, 低価格化が実現されている。しかし, 垂直記 録方式が採用されており，さらに高密度記録を達成するため にはへッド・媒体の隙間をできるだけ小さくする必要があ $3^{1), 2)}$ 。そのためには, 保護膜厚の低減が欠かせず, 磁気へッ ドの磁気ディスクへの接触による損傷からの耐久性を維持す ることが求められている ${ }^{3)}$ 。

ヘッド・媒体インターフェースでは極微小荷重, 高速条件 におけるトライボロジカルな現象が生じるので，極表層の物 性がトライボロジー特性に影響を与えている。現状では磁気 デイスク装置の信頼性を確保するため, $5 \mathrm{~nm}$ 以下の DLC 膜 などの保護膜および $1 \mathrm{~nm}$ 程度のパーフロロポリエーテル (PFPE : Perfluoropolyether) 潤滑油が用いられており, 潤滑油 の保護膜への付着力を改善するための表面改質技術が重要に なっている ${ }^{4), 5)}$ 。たとえば，PFPE 潤滑油に対して紫外線照 射 ${ }^{6}$ や熱処理 ${ }^{7)}$ な゙が検討されている。しかし，処理の効果， メカニズムについては不明な部分が多く, 表面での潤滑油の

\footnotetext{
*E-mail : s1014219@sstu.nit.ac.jp
}

状態, 保護膜との付着力などの知見を得ることは重要であ $3^{8)}$ 。

著者らは垂直磁気ディスクに扔ける横振動摩擦摩耗試験 ${ }^{9)}$, 粘弾性の評価から結晶粒界に起因する潤滑油の供給効果 ${ }^{10)}$ におよぼす熱処理の影響を明らかにしてきた ${ }^{7), 11) 。 さ ら に, ~}$ 紫外線照射処理を行った磁気デイスクについて, 摩擦力と電 流分布を評価し，潤滑油の挙動を明らかにしてきた ${ }^{6)}$ 。

本報告では, 紫外線照射処理, 熱処理掞よび未処理の垂直 磁気ディスク上の潤滑油に対して, 原子間力顕微鏡を用いた ナノメートルスケールの変形特性とボールオンデイスク型試 験 ${ }^{12)}$ を行った結果を報告する。

\section{2. 実験方法}

\section{1 試 料}

垂直磁気ディスクに潤滑油を塗布したものを試験片として 使用した。保護膜にはDLC (Diamond-like Carbon)を用い, 膜厚は約 $10 \mathrm{~nm}$ とした。潤滑油には直鎖構造を有する Fomblin 系 PFPE 潤滑油 Zdol2000 (SolvaySolexis 社), 分子数 2000，末端の官能基として $-\mathrm{CH}_{2}-\mathrm{OH}$ の水酸基を有している。 膜厚は約 $1.1 \mathrm{~nm}$ である。これに紫外線照射処理として, 潤滑 油と保護膜の結合を促すと考えられる波長 $254 \mathrm{~nm}$ の紫外光 を低圧水銀ランプにて 80 秒間照射したもの, 熱处理として, 比較的ボンディング比が高くできる $100^{\circ} \mathrm{C}$ の恒温槽で 15 分 間処理をしたものを使用した。さらに比較のため未処理の試 
料を用いた。ボンディング比とはディスク表面に固着してい る潤滑油量と固着していない潤滑油量の比率を指す。潤滑油 塗布初期後の膜厚を計測し, その後フッ素系溶剂で洗浄, 残 存膜厚を X 線光電子分光法にて計測し, 全膜厚と残存膜厚 の比から算出した。未処理磁気ディスクの潤滑油のボンデイ ング比 $0 \%$ に対して，紫外線照射処理を行った潤滑油は重合 が進み，ボンディング比は約 $20 \%$ ，熱処理を行ったものは 約 $80 \%$ 程度になっている。ボンディング比の高い潤滑油は 処理によって保護膜と結合しているか，または，重合反応に より分子量が増大している。なお，潤滑油と保護膜との結合 メカニズムおよび潤滑油の重合反応の有無等は不明であるが, 溶剤で洗浄されなかった潤滑油を固定層とよび, 洗浄により 取り除かれた潤滑油を流動性のある潤滑油とした。

\section{2 ナノインデンテーションによる変形特性の評価}

紫外線照射処理, 熱処理を施した潤滑油の変形特性を評価 するため, ナノインデンテーション試験を行った。図 1 に概 略を示す。先端半径約 $200 \mathrm{~nm}$ のベルコビッチ型ダイヤモン ド圧子を使用した。試験時の荷重は $10 \sim 100 \mu \mathrm{N}$ である。押 し込み時間は負荷時 5 秒, 除荷時 5 秒とした。

\section{3 ナノ摩耗試験と摩耗部のフォースモジュレーショ ンによる粘弾性評価}

潤滑油の摩擦後の移動状況を確認するためにナノ摩耗試 験 ${ }^{13)}$ 箇所におけるフォースモジュレーションを用いた粘弾

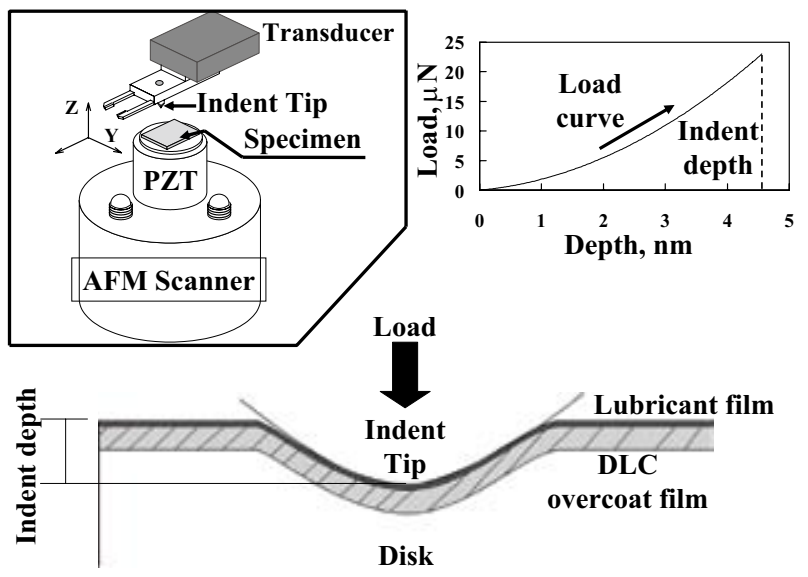

Fig. 1 Nanoindentation test for evaluating of nanometer-scale deformation properties.

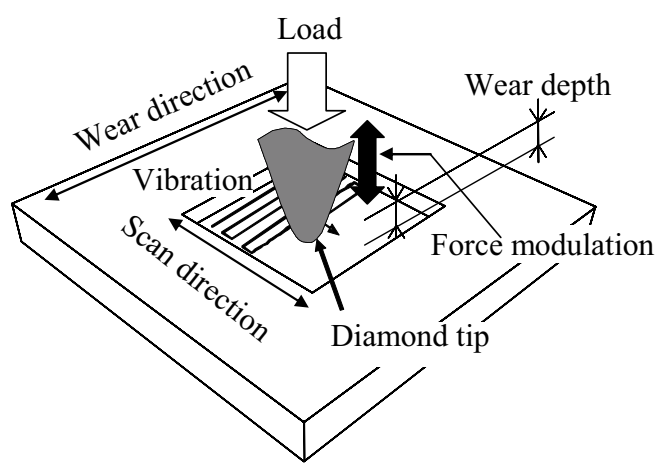

Fig. 2 Viscoelastic evaluation method by force modulation after nanowear test.
性評価を行った。図 2 に概略を示す。先端半径約 $200 \mathrm{~nm}$ の ベルコビッチ型ダイヤモンド圧子を試験箇所に押し付け, ロックインアンプより Z 方向にフォースモジュレーション を付加し ${ }^{7)}$, トランスデューサーにより検出された変位, 位 相遅れから貯蔵弾性率：E’ と損出弾性率：E”を算出した。 さらに(1)式より粘弾性 $\operatorname{Tan} \delta$ を求めた。

$\operatorname{Tan} \delta=\mathrm{E}^{\prime \prime} / \mathrm{E}^{\prime}$

ナノ摩耗試験は試験荷重を $5 \mu \mathrm{N} \sim 20 \mu \mathrm{N}$ とした。図中の Wear direction は摩耗試験の摩擦方向を, Scan direction はチッ プの走査方向を示す。フォースモジュレーションを用いた粘 弾性評価では, 荷重振幅は $5 \mu \mathrm{N}$, 周波数は $300 \mathrm{~Hz}$, 測定時に 荷重を $10 \mu \mathrm{N} \sim 50 \mu \mathrm{N}$ と変化させた。また，フォースモジュ レーションを用いた粘弾性評価はナノ摩耗試験直後に行った。 摩耗部の深さを平均し, 未摩擦部との差を摩耗深さとした。 ナノインデンテーション試験とナノ摩耗試験およびフォース モジュレーションを用いた粘弾性評価は同一の装置を用いて 行った。

2. 4 ボールオンディスク型摩擦摩耗試験による摩擦特 性評価

ボールオンディスク型摩擦摩耗試験機を用い, トライボロ ジー特性の評価を行った。圧子には SUS440C $\phi 6 \mathrm{~mm}$ を用いた。 総回転数は 1800 回。回転半径は $5.0 \mathrm{~mm}$, 回転数は $60.0 \mathrm{rpm}$ 。 回転速度は $31.4 \mathrm{~mm} / \mathrm{s}$ である。試験終了後, 基板と圧子の損 傷状態を光学顕微鏡にて観察した。

\section{3. 実験結果および考察}

\section{1 ナノインデンテーションによる磁気ディスク表面 の変形特性}

図 3 にカンチレバーを一定周波数で振動させ, 形状を測定 する DFM (Dynamic Force Modulation)を用い測定した未処理 の表面形状を示す。表面形状像より，垂直型磁気ディスク特 有の結晶粒界が確認できる。高くなっている結晶部を丘部, 低くなっている結晶粒界部を溝部とした。潤滑油は均一に塗 布されているが，丘部と溝部では潤滑油の存在量が異なり, それがトライボロジー特性に影響を与えていると考えられる。 このため, ナノインデンテーションによる評価を行った。

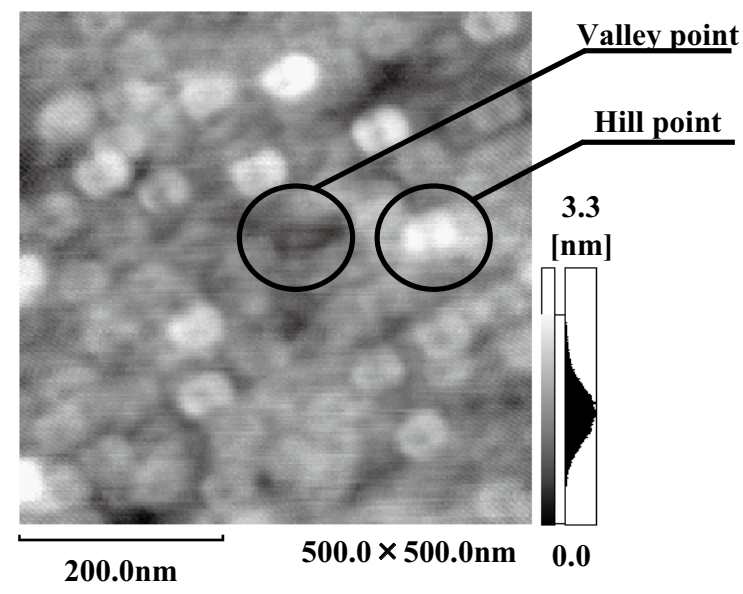

Fig. 3 Image of surface profile by DFM. (Non treatment) 
図 4 (a)に最大荷重 $20 \mu \mathrm{N}$ 時の磁気ディスク表面の丘部, (b)に溝部におけるナノインデンテーションカーブを示す。 (a)の丘部では最大変形量が未処理で約 $4.0 \mathrm{~nm}$, 熱処理で約 $4.4 \mathrm{~nm}$, 紫外線照射処理で約 $4.5 \mathrm{~nm}$ と各試料の差は少ない。 (b)の溝部ではインデント時の最大変形量は未処理で, 約 $4.8 \mathrm{~nm}$, 熱処理では約 $4.0 \mathrm{~nm}$, 紫外線照射処理では約 $2.8 \mathrm{~nm}$ である。

図 5 (a)に各試料の丘部, (b)に溝部における最大変形量の 荷重依存性を示す。丘部の最大変形量では, ばらつきが大き く, 各試料に有意な差は見られない。溝部においては図 5 (b) に示すように, 未処理で最も変形量が大きく, 荷重の増加と ともに増大している。処理の効果は溝部で見られ, 最も変形 量が少ないのは紫外線照射処理を施したものである。

ナノインデンテーション試験では, 垂直方向の弾塑性的な 変形特性が得られ, 低荷重では主に流動層, 固定層を含む潤 滑油, 高荷重では DLC 保護膜を含めた潤滑油の変形特性が 得られると考えられる。熱処理は固定される層が増大し, ナ ノインデンテーションのような縦方向の力には大きな変形抵 抗を示すと考えられる。しかし, 比較的高荷重になると特に 溝部でインデント深さはUV 処理に比べ大きくなっている。 この原因は明確ではないが再現性があり，処理によって潤滑 油の DLC との結合力および構造が溝部で変化していること が原因と考えられる。

3. 2 ナノ摩耗試験と摩耗部のフォースモジュレーショ ンによる粘弾性評価

ナノメータースケールの潤滑油と保護膜を含めた耐摩耗性

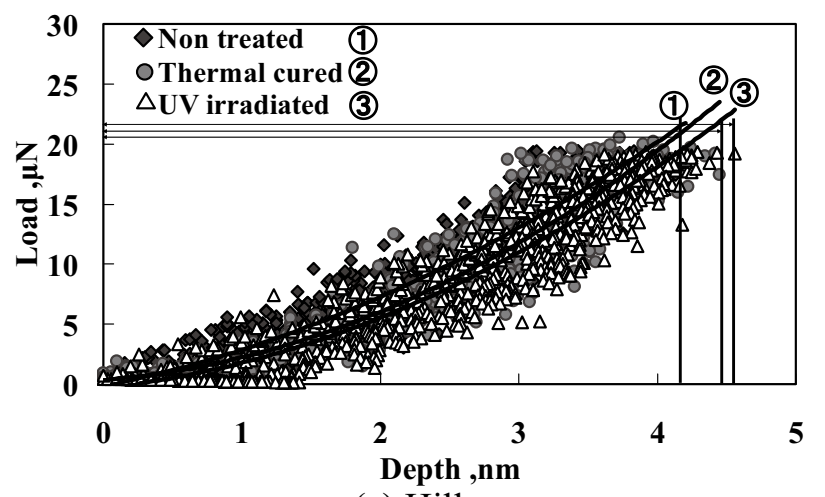

(a) Hill

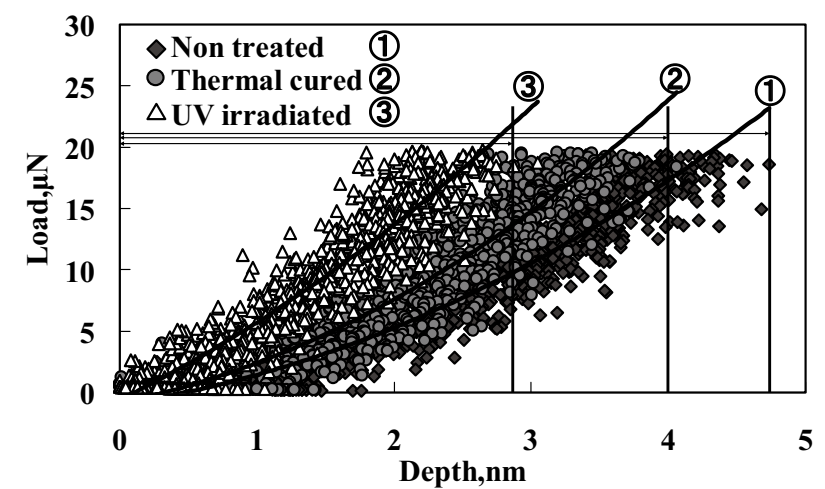

(b) Valley

Fig. 4 Nanoindentation curve at $20 \mu \mathrm{N}$ load of lubricant-coated magnetic disk.
の評価として, 図 6 に摩耗試験前と約 $1.7 \mathrm{~nm}$ 深さの摩耗が観 察できる代表的なナノ摩耗試験(荷重 : $15 \mu \mathrm{N}$ ) の結果を示す。 摩耗深さは, 枠の部分を平均断面として算出した。図 7 にナ ノ摩耗試験における摩耗深さの荷重依存性を示す。低荷重領 域の荷重 $5 \mu \mathrm{N} \sim 20 \mu \mathrm{N}$ では熱処理で摩耗深さが大きく, 未 処理で最も摩耗が小さい。熱処理では固定される潤滑油が増 大するので, 可動成分が減少し, 摩擦が生じた場合, 損傷部 に補給される潤滑油が減少して摩耗が増大すると考えられる。

図 8 に摩耗前の磁気ディスク表面の丘部(a), と溝部(b)に おけるフォースモジュレーションによる粘弾性評価を行った 結果を示す。丘部において未処理, 紫外線照射処理, 熱処理

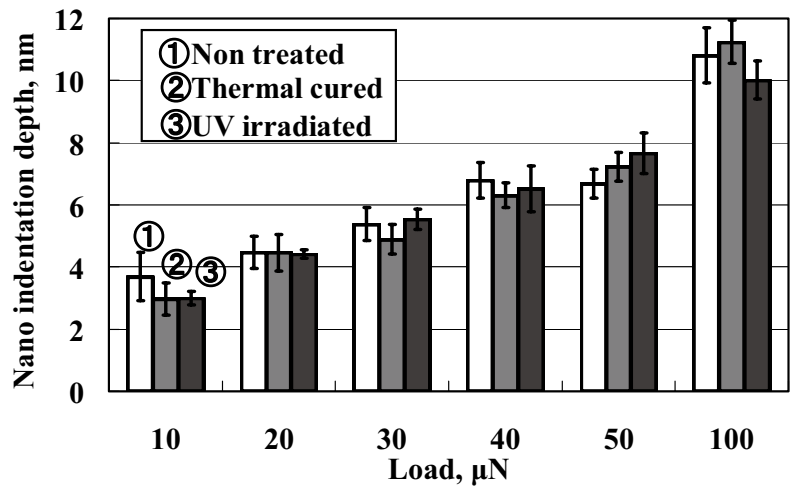

(a) Hill

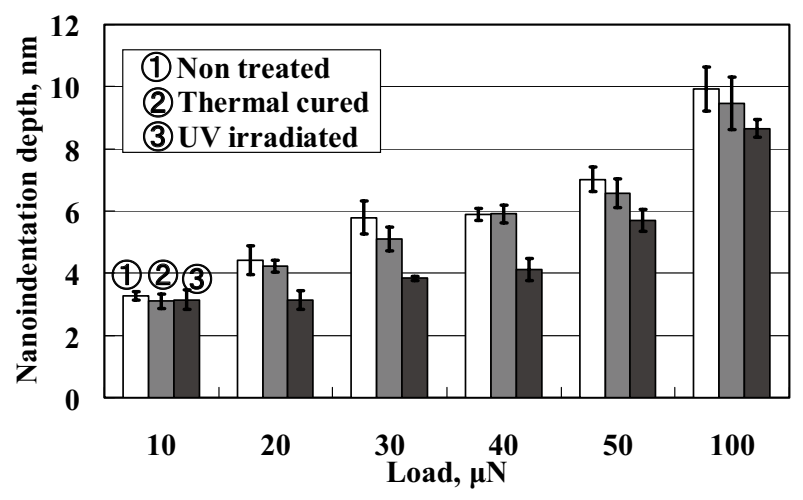

(b) Valley

Fig. 5 Nanoindentation depth dependence on load.

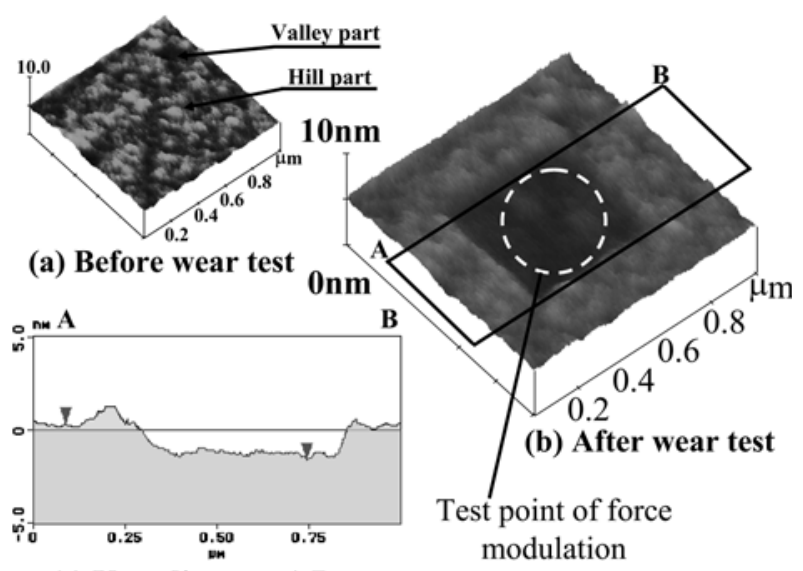

(c) Vert distance: $1.7 \mathrm{~nm}$

Fig. 6 Nanowear profile and depth of lubricant-coated magnetic disk. (Non treated lubricant on magnetic disk) 


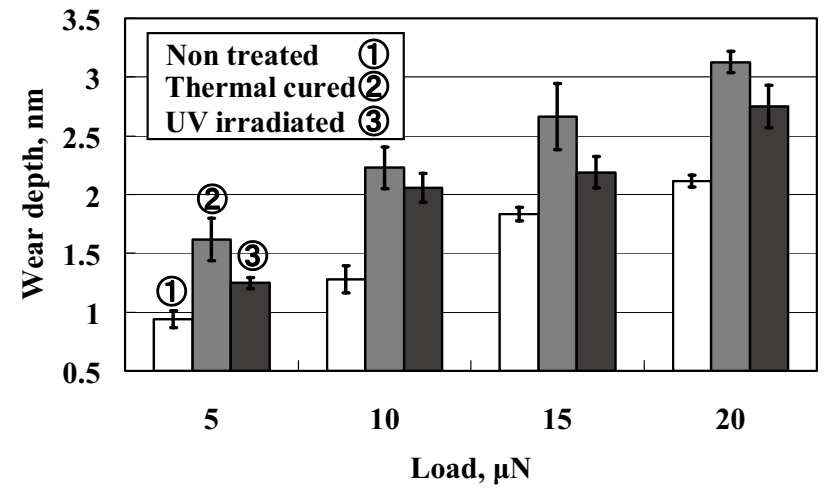

Fig. 7 Nanowear depth dependence on load of lubricant-coated magnetic disk.

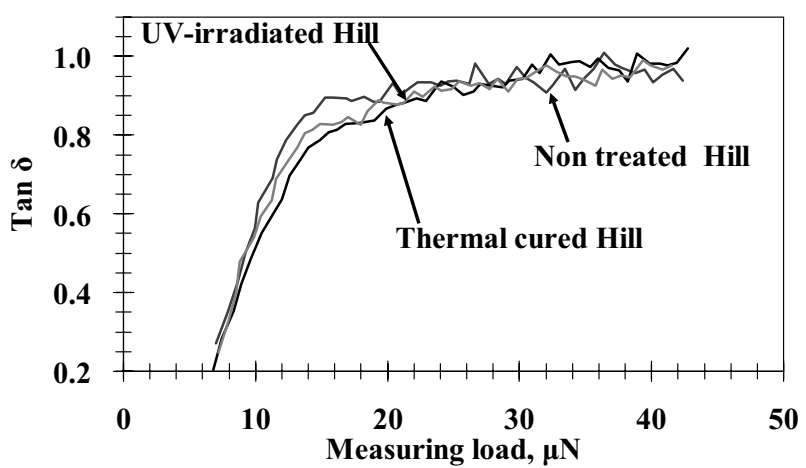

(a) Hill

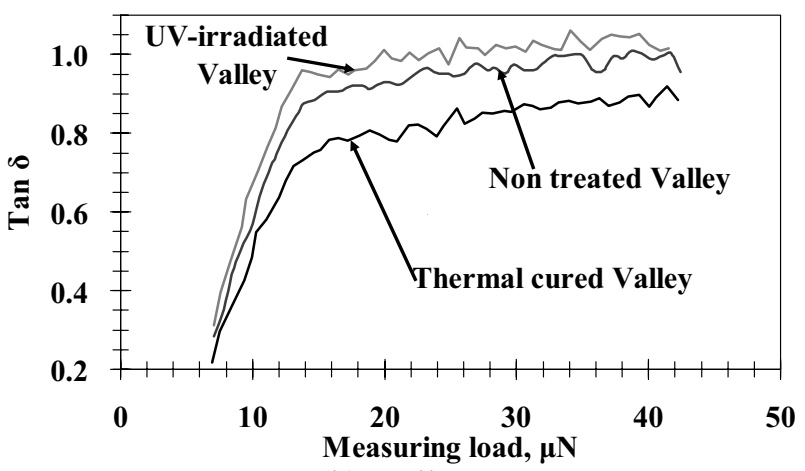

(b) Valley

Fig. $8 \operatorname{Tan} \delta$ dependence on tested load before nanowear test.

ともに, Tan $\delta$ は 0.93 程度を示す。これに対して溝部におい ては, 未処理, 紫外線照射処理では Tan $\delta$ は $0.96,1.01$ 程度 と丘部に対して増加する。一方熱処理では 0.84 程度に著し

く減少している。

図 9 に摩耗前における溝部の Tan $\delta$, 摩耗試験部における $\operatorname{Tan} \delta$ を他の試料と比較するため, 接触状態が安定する $15 \mu \mathrm{N}$

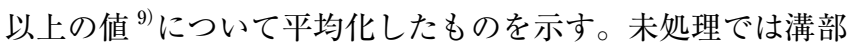
の $\operatorname{Tan} \delta 0.96$ から摩耗後 1.00 程度に増大する。熱処理では摩 耗前の Tan $\delta 0.84$ 程度に比べて摩耗後 0.96 と増大している。 紫外線照射処理では, 摩耗前後での差は少ない。

摩耗後の Tan $\delta$ は未処理で最も高く，熱処理では低い。紫 外線照射処理は未処理と中間の值を示している。また摩耗荷 重の増大に従い Tan $\delta$ は減少していることから, 摩耗深さの 増大に従い補給効果が減少していると考えられる。

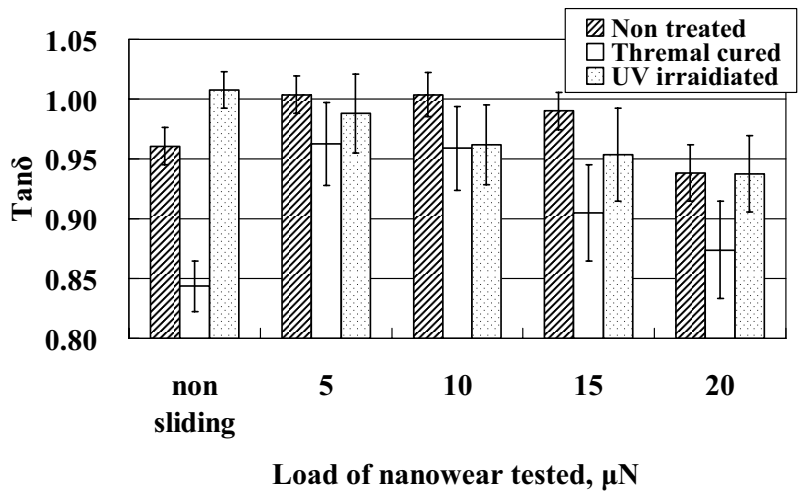

Fig. 9 Medians of $\tan \delta$ after nanowear test.

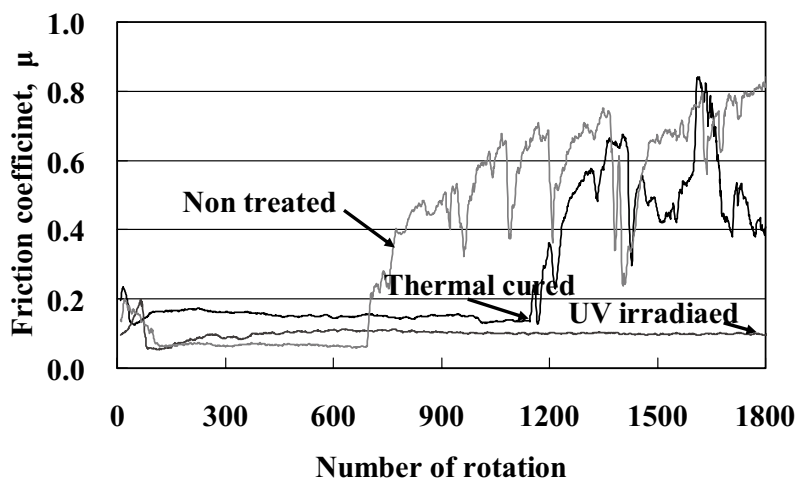

Fig. 10 Friction coefficient dependence on sliding cycle by ball-ondisk.

ナノ摩耗後の摩耗部の粘弾性評価は各処理を行うことによ る摩耗部の Tan $\delta$ の減少と対応し, 特に熱処理では処理によっ てボンディング比が著しく増大したので, 自由な潤滑油が減 少して摩耗部へ補給される潤滑油が少なくなり, そのため $\operatorname{Tan} \delta$ が減少したと考えられる。さらに，紫外線照射処理は 熱処理と異なり $\operatorname{Tan} \delta$ は増加しており, 流動性が維持され潤 滑油が補給されていると考えられる。

\section{3 ボールオンディスク型摩擦摩耗試験による摩擦特 性}

図 10 にボールオン型摩擦摩耗試験機の試験結果を示す。 未処理では試験開始後 700 回まで摩擦係数は約 0.05 程度を 示し, その後摩擦係数が増大する。熱処理では試験開始後の 摩擦係数は約 0.18 程度を示すが, 摩擦回数約 1200 回付近で 摩擦係数が増大する。紫外線照射処理では摩擦係数の急激な 増大は見られない。

図 11 に試験後の圧子と基板表面を示す。未処理では試料 側に損傷が見られる。熱処理では未処理の試料と比べて損傷 幅, 損傷が増大しており, 処理によって補給効果が減少して いると考えられる。一方, 紫外線照射処理では激しい損傷は 見られない。これはボンディング比増大による固定層の増加

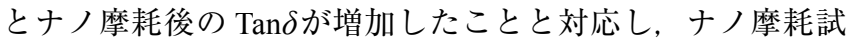
験では潤滑油の補給効果が観察されていると考えられる。し たがって, ボールオンディスク型摩耗試験の紫外線照射処理 においては，固定層による耐久性の向上と流動性による補給 効果によって潤滑性向上が実現したと考えられる。 

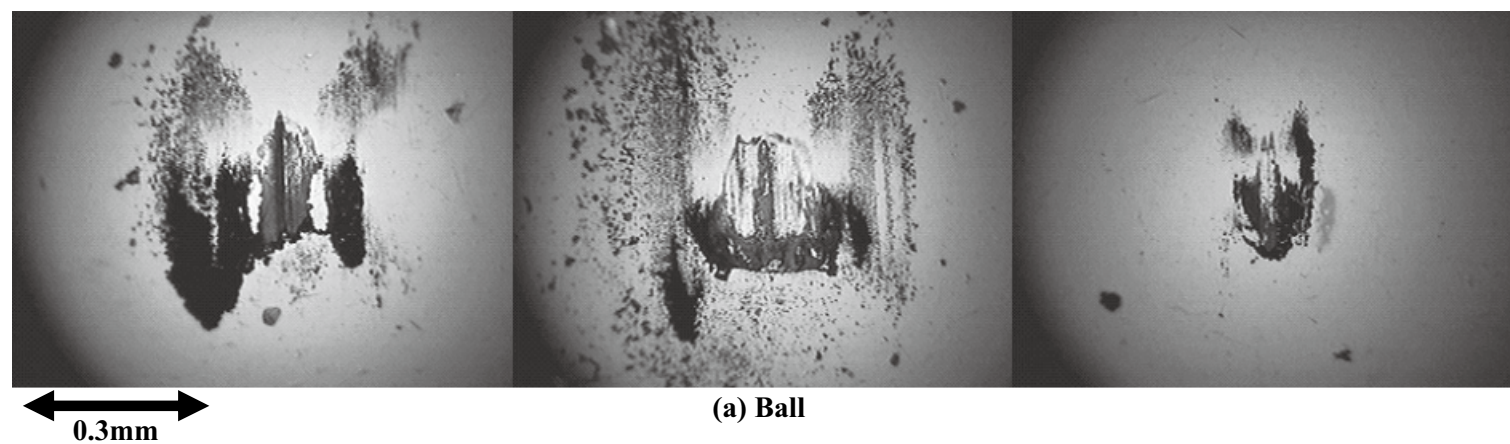

(a) Ball

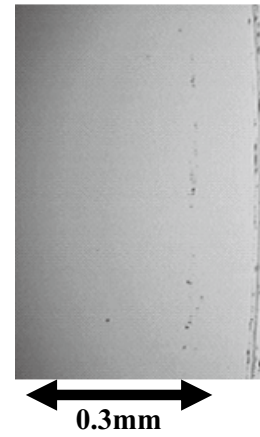

Non treated
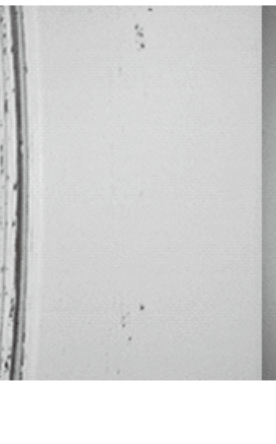

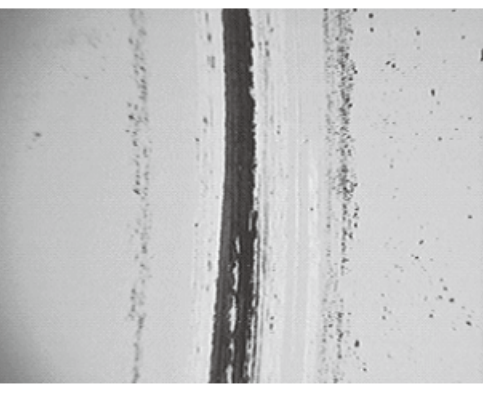

(b) Disk

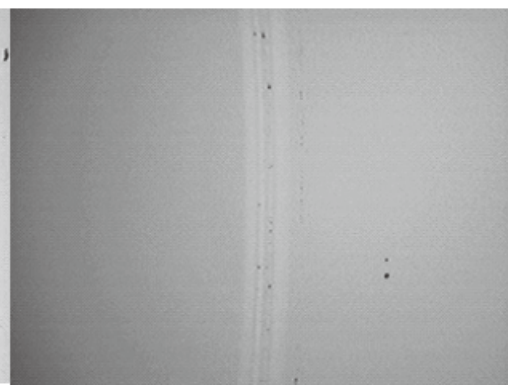

Thermal cured

UV irradiated

Fig. 11 Surfaces of ball and disk after ball-on-disk friction tests.

\section{4. 結 論}

紫外線照射処理, 熱処理および未処理の垂直磁気ディスク 上の潤滑油について，原子間力顕微鏡を用いたナノメートル スケールの力学特性評価とボールオンディスク型摩擦摩耗試 験を用いた潤滑油耐久性評価から，以下の結果を得た。

(1)ナノインデンテーションを用いた潤滑油の保護膜を含め た力学特性の評価では, 熱処理, 紫外線照射処理により硬 化し, 処理の効果によって変形量が減少する。特に紫外線 照射処理の変形量が最も少ない。処理によって潤滑油の DLC との結合力および構造が溝部で変化していることが 考えられる。

(2) 摩耗部における粘弾性評価より, 熱処理を行うことで, 摩耗部に補給される潤滑油が減少し, 摩耗が増大すると考 えられ，未処理では流動する潤滑油が最も多いと考えられ る。摩耗は少ない紫外線照射処理では摩耗前の粘弾性評価 結果より潤滑油は特に溝部に存在し, 補給効果はほとんど 減少しないと考えられる。

(3) 各処理を施した磁気ディスクで, ボールオンディスク型 摩擦摩耗試験を行った結果, 特に紫外線照射処理で低摩擦 を示し，損傷も少ない。これらのトライボロジー特性の向 上は固定された潤滑油の存在と, 流動性のある潤滑油によ る補給効果とが適切に作用したためと考えられる。

\section{謝 辞}

本研究の一部に情報ストレージ研究推進機構 (SRC) および
日本学術振興会科学研究費補助金(平成 18 年度基盤研究 $(C)$, 18560140)の援助を活用した。

(Received June 30, 2008 ; Accepted January 30, 2009)

\section{文献}

1) B. Bhushan ; Tribology and mechanics of magnetic storage devices, (Springer-Verlag, 1990).

2 ) K. E. Johnson, C. M. Mate, J. A. Merz, R. L. White and A. W. Wu ; IBM J. Res. Dev., 40, 511 (1996).

3 ) R. Kaneko, S. Oguchi, T. Miyamoto, Y. Andoh and S. Miyake; STLE Publication, SP-27, 31 (1990).

4 ) S.Miyake ; Trans. of Jpn. Mat. Res. Soc., 15B, 919 (1994).

5 ) S.Miyake and M. Wang ; Jpn. J. Appl. Phys., 43, (6A), 3566 (2004).

6 ) S. Miyake, S. Ninomiya and M. Wang; Jpn. J. Appl. Phys., 44, (9), L299 (2005).

7 ) T. Saitoh, S. Miyake and S. Matsunuma; Microsyst. Technol., 11, (8), $1138(2005)$

8 ) S.Miyake; J. of Vac. Sci. \& Technol. B, 21, (2), 785 (2003).

$9)$ S. Miyake, Y. Takahashi, M. Wang and T. Saito ; J. Phys. D : Appl. Phys., 38, (13), 2244 (2005).

10) S. Miyake, Y. Takahashi, M. Wang, T. Saitoh and S. Matsunuma; Jpn. J. Appl. Phys., 43, (11B), L1469 (2004).

11) S. Miyake, M. Wang and S. Ninomiya ; Surf. Coat. Technol., 200, (2021), 6137 (2006)

12) S. Miyake, Y. Sekine, J. Noshiro and S. Watanabe ; Jpn. J. Appl. Phys., 43, (7A), 4338 (2004).

13) S. Miyake ; Appl. Phys. Lett., 65, (8), 980 (1994). 